\title{
An Algorithm for Automatically Modifying Train Crew Schedule
}

\author{
Satoru Takahashi Member (Mitsubishi Electric Corporation) \\ Kenji Kataoka Member (Mitsubishi Electric Corporation) \\ Teruhito Kojima Non-member (East Japan Railway Company) \\ Masayuki Asami Member (East Japan Railway Company)
}

Keywords: crew re-scheduling, combinational problem, meta-heuristics, taboo search

Once the break-down of the train schedule occurs, the crew schedule as well as the train schedule has to be changed as quickly as possible.

In this paper, we aim to automatically modify a crew schedule that takes all constraints into consideration, presenting a model of the combined problem of crews and trains, and proposing an algorithm that rapidly computes a constraint satisfaction solution.

When the train schedule is revised due to a schedule break down, constraint violations can occur in the crew schedule if it is applied to the revised train schedule. The time following the earliest of these violations is subject to reallocation, and the sections of duties, the train crewing schedule of a particular crew member incorporating a combination of trains, after this time are divided into segments by train. And our algorithm consisting of two steps is applied, that is, the initial solution is created in the $1^{\text {st }}$ step and the solution is revised in the $2^{\text {nd }}$ step.

In the $1^{\text {st }}$ step, the initial solution is created by allocating the trains resulting from duty decomposition, excluding the working time upper and lower bound constraints. In order to improve the quality of the initial solution, allocation rules based on know-how used by experts when deciding allocations manually are applied, and duties that conform to these rules are selected as candidates to that each train can be allocated. After selecting several candidates from the existing duties, the selection criteria are used to narrow the candidates down to one choice, that is, each selection criterion is applied and candidates for which the criterion does not apply are eliminated. If this results in only one candidate duty, the train is assigned to that duty. If there are still multiple candidates, the remaining criteria are applied in order. If all of the candidates are eliminated by any of the criteria, that criterion is skipped. If a candidate duty is not selected by all rules, it is assigned to a crew supervisor, or a designated leader. And if a leader is not available or he/she cannot reach the starting station in time, the constraint level is relaxed or the train is assigned to a buffer duty. An executable solution is created by searching for a way to move it to a real duty on the $2^{\text {nd }}$ step, the solution revisions.

In the $2^{\text {nd }}$ step, the work-time constraint violations not considered when creating the initial solution are eliminated by making revisions to the initial solution. The revision is done by repeatedly changing trains among duties, shown in Figure 1. And, taboo search, one of meta-heuristics algorithms, is used to avoid becoming trapped in local solutions. The history of trains moved between duties is stored in a taboo list and train movements that have already been examined are excluded from the search. The taboo list is allowed unlimited length, but is cleared when a solution better than the current best is found. We also define a degree of differentiation value, reflecting the number of trains that are different from those in the current best solution. The search is terminated when the degree reaches a certain threshold.

Finally, in order to demonstrate the effectiveness of the proposed algorithm, we applied it to two actual cases of schedule break-down that occurred in one of the major lines in the Tokyo urban area, and compared it with the manual modifications by human experts, shown in Table 1. It indicates that the algorithm can create workable solutions in a short period of time that are evaluated at least as favorably as the manually-created solutions.

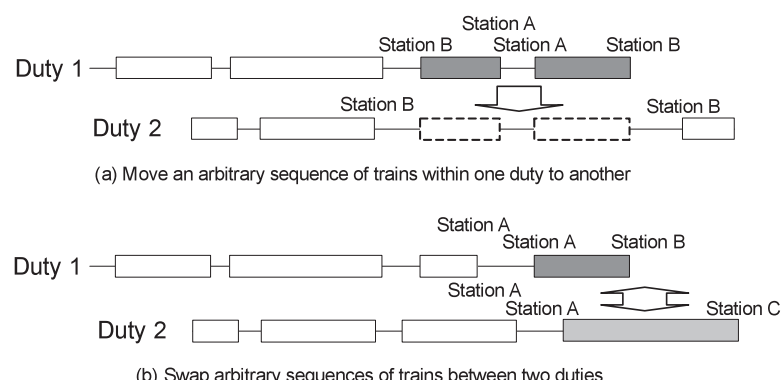

(b) Swap arbitrary sequences of trains between two duties

Fig. 1. Examples of duty revision operations

Table 1. Comparison of Manually and automatically generated modifications

\begin{tabular}{|c|c|c|c|c|c|c|c|c|}
\hline \multirow[b]{2}{*}{ Case } & \multirow[b]{2}{*}{ Type } & \multicolumn{2}{|c|}{ Working hours } & \multirow{2}{*}{$\begin{array}{l}\text { No. of shares } \\
\text { (\# trains) }\end{array}$} & \multirow[b]{2}{*}{ Plan ratio } & \multirow{2}{*}{$\begin{array}{l}\text { Reserve } \\
\text { crews } \\
\text { (\# crews) }\end{array}$} & \multirow{2}{*}{$\begin{array}{c}\text { Changed crews } \\
\text { (\# crews) }\end{array}$} & \multirow{2}{*}{$\begin{array}{l}\text { Computing } \\
\text { time (s) }\end{array}$} \\
\hline & & $\begin{array}{l}\text { Absolute value } \\
\text { (s) }\end{array}$ & $\begin{array}{l}\text { Relative } \\
\text { increase }\end{array}$ & & & & & \\
\hline \multirow{2}{*}{1} & Manual & 3672110 & - & 59 & $95.4 \%$ & 2 & 14 & - \\
\hline & Automatic & 3656790 & $-0.42 \%$ & 60 & $96.5 \%$ & 0 & 15 & 3.7 \\
\hline \multirow{2}{*}{2} & Manual & 3679270 & - & 68 & $96.9 \%$ & 2 & 39 & - \\
\hline & Automatic & 3660040 & $-0.53 \%$ & 65 & $96.7 \%$ & 2 & 32 & 10.2 \\
\hline
\end{tabular}

\# Machine Performance: (CPU) Pentium 4-2.8GHz, (Memory) $1 \mathrm{~GB}$ 


\title{
ダイヤ乱れ時における列車乗務員運用整理案の自動作成
}

\author{
正 員 高橋 理* 正 員 片岡 健司* \\ 非会員 小島 央士** 正 員 浅見 雅之**
}

An Algorithm for Automatically Modifying Train Crew Schedule

Satoru Takahashi*, Member, Kenji Kataoka*, Member, Teruhito Kojima**, Non-member, Masayuki Asami**, Member

Once the break-down of the train schedule occurs, the crew schedule as well as the train schedule has to be modified as quickly as possible to restore them. In this paper, we propose an algorithm for automatically modifying a crew schedule that takes all constraints into consideration, presenting a model of the combined problem of crews and trains. The proposed algorithm builds an initial solution by relaxing some of the constraint conditions, and then uses a Taboo-search method to revise this solution in order to minimize the degree of constraint violation resulting from these relaxed conditions. Then we show not only that the algorithm can generate a constraint satisfaction solution, but also that the solution will satisfy the experts. That is, we show the proposed algorithm is capable of producing a usable solution in a short time by applying to actual cases of train-schedule break-down, and that the solution is at least as good as those produced manually, by comparing the both solutions with several point of view.

キーワード：乗務員運用整理, 組合せ問題, メタヒューリスティクス, タブーサーチ

Keywords: crew re-scheduling, combinational problem, meta-heuristics, taboo search

\section{1. はじめに}

鉄道は最も重要な社会インフラの 1 つであり，天候や事 故による列車運行の乱れはわれわれの生活に大きな影響を 及ぼす。したがって，列車運行が乱れた場合にはただちに 早期復旧を目的とした運転整理（列車ダイヤの変更）が行 われるが，それにあわせて乗務員運用整理（乗務員運用計 画の変更) ${ }^{(1)} も$ 必要になることが多い。この乗務員運用整 理業務では, 乗務員の労働条件や移動上の制約条件を勘案 しながらすべての列車に乗務員を割り当てなくてはならな い。これは, 熟練した技術を必要とする負荷の高い業務で あり，現状では乗務員区所にいる区所当直らの手作業で行 われている。しかしながら, 近年, こうした熟練社員が減 少しているほか, 列車の高密度化や鉄道事業者間での相互 乗り入れなどにより運行計画は複雑化しているため, 担当 者の負荷はますます高くなっている。この結果として乗務

\footnotetext{
* 三菱電機 (株) 先端技術総合研究所

干 661-8661 尼崎市塚口本町 8-1-1

Advanced Technology R\&D Center, Mitsubishi Electric Corporation

8-1-1, Tsukaguchi-honnmachi, Amagasaki 661-8661

** 東日本旅客鉄道 (株) JR 東日本研究開発センター

テ331-8513 さいたま市北区日進町 2 丁目 479 番地

Research and Development Center of JR East Group, East Japan

Railway Company

2-479, Nisshin, Kita-district, Saitama 331-8513
}

員の手配に長い時間を要したり, 手配漏れが発生し, 輸送 混乱を一層拡大させてしまう場合もある。一部では熟練者 の作業軽減を目的に, 計算機の導入も始まっているものの, 計算機は人手で作成した計画やその矛盾 (制約条件違反) を 画面上に表示したり，矛盾解消のための編集機能を提供す るなど，人手による作成業務を支援しているにすぎない。

そこで，本論文では，すべての制約条件を勘案した乗務 員運用整理案の自動作成を目的として, 乗務員運用整理問 題を乗務員に対して列車の割当を行う組合せ問題としてモ デル化し，この制約充足解を高速に求めるアルゴリズムを 提案する。また，計算機による自動作成が実用的なレベル にあることを示すには，アルゴリズムが単に制約充足解を 出すことができるというだけでなく, 自動作成した整理案 の方が現在熟練者の手により作成されている整理案よりも 優れていることを示す必要がある。そこで, 首都圈にある 実際の路線を対象に提案手法を適用して作成した整理案と 同路線の区所当直らの手により作成された整理案の比較結 果を示し，提案手法の有効性を評価する。

\section{2. 乗務員運用整理案の作成}

$\langle\mathbf{2} \cdot \mathbf{1}\rangle$ 概 要 Fig.1は列車ダイヤを示したもの で, 縦軸に路線上の駅, 横軸に時刻を配し, 斜線は列車の 運行状態を表す。また, 斜線のうちの太線部分は, ある乗 務員が勤務開始時刻から勤務終了時刻までの間に行う列車 


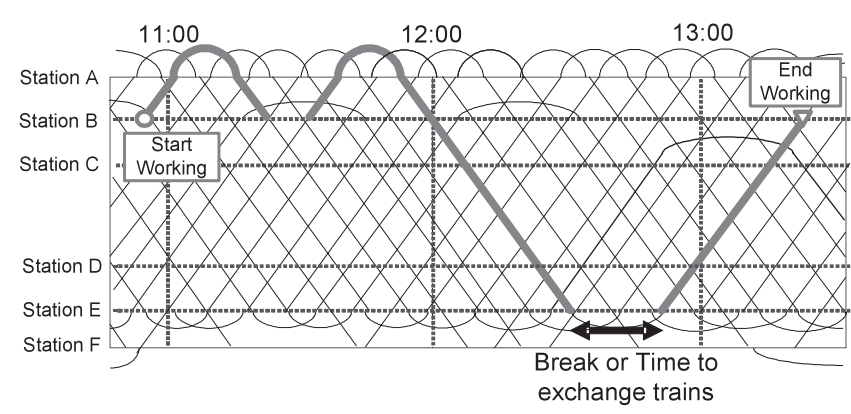

Fig. 1. Example of a train schedule and a crew duty.

乗務スケジュールを示すもので「行路」と呼ぶ。すなわち， 行路は乗務員の勤務時間を示す枠であり，すべての制約条 件を満たすような列車の組合せが入る。

このとき, 計画ダイヤに基づき, 乗務員の労働条件や移 動上の物理制約などの制約条件を満たすように，事前にす べての列車をいずれかの行路に割り当てる業務が乗務員運 用計画である。これに対して，乗務員運用整理とは，災害 や事故などによって列車運行の乱れが発生した場合に，運 転整理によって修正された列車ダイヤに基づいて，すべて の列車をいずれかの行路に割り当て直すものである。

$\langle\mathbf{2} \cdot \mathbf{2}\rangle$ 制約条件 乗務員運用計画の作成においては, 乗務員の労働条件をはじめとして Table 1 に示すような制 約条件が定められているが，ダイヤ乱れ時に打ける乗務員 運用整理案の作成においては, 労働条件の充足よりも列車 運行の早期復旧が優先される。このため, 現状では運用整 理案作成には明確な制約条件が設定されておらず，労働条 件を超過する整理案が作成されることも多い。

特に, 高密度線区では多くの列車が短い間隔で走行する ため, ある列車の遅延が多数の列車に影響を及ぼし，ダイ ヤ乱れ時には非常に多くの制約違反が発生する。このため, 熟練者が短時間にすべての制約違反を解消する運用整理を 行うことは困難であり，その結果，乗換駅の一致など物理 的な制約条件のみを満たす整理案を作成するだけで精一杯 で，乗務員の労働条件まで考慮することができず，乗務員 に過度な労働を強いる場合も多いのが現状である。

$\langle\mathbf{2} \cdot \mathbf{3}\rangle$ 目的関数 乗務員運用計画の作成時には, 乗務 員の効率的な利用を目的として, 労働時間や便乗時間（運 転業務をせずに次乗務列車の乗務開始駅までの移動のため に別の列車に乗車する時間）の総和を最小化するといった 目的関数を定義することが可能であるが，ダイヤ乱れ時の 運用整理案作成においては, 制約条件の充足よりも列車運 行の早期復旧が優先されるため, 明確な目的関数は定義さ れていない。

定性的には，早期に乱れを収束する，計画からの変更量 を少なくするといった目標はあるものの, 乗務員も人であ るので, 円滑・快適に業務を遂行してもらうためには効率 のみを重視した運用整理案は必ずしも現場に受け入れられ ない。また，熟練者にとっての理想的な運用整理案の定義 はあいまいで，人によっても異なるため，一意に決定する
Table 1. List of Constraints.

\begin{tabular}{|l|l|}
\hline Item & Description \\
\hline \hline $\begin{array}{l}\text { Number of } \\
\text { crew members }\end{array}$ & No more than a set number of crew members \\
\hline $\begin{array}{l}\text { Elimination of } \\
\text { non-crewed }\end{array}$ & All trains must have a crew \\
\hline $\begin{array}{l}\text { Connection } \\
\text { matching }\end{array}$ & $\begin{array}{l}\text { Matching the final stop of a train with the } \\
\text { starting station of the next train to be crewed }\end{array}$ \\
\hline Meal times & $\begin{array}{l}\text { Securing the necessary breaks during meal } \\
\text { times }\end{array}$ \\
\hline $\begin{array}{l}\text { Continuous } \\
\text { shifts }\end{array}$ & $\begin{array}{l}\text { Creating continuous crew shifts without } \\
\text { breaks and within the maximum shift length }\end{array}$ \\
\hline $\begin{array}{l}\text { Work-time } \\
\text { bounds }\end{array}$ & $\begin{array}{l}\text { Restrict deviation of working hours from plan } \\
\text { to within a certain threshold }\end{array}$ \\
\hline $\begin{array}{l}\text { Final } \\
\text { destination }\end{array}$ & $\begin{array}{l}\text { Match final station with planned } \\
\text { work-completion station }\end{array}$ \\
\hline
\end{tabular}

\section{ことは困難である。}

$\langle\mathbf{2} \cdot \mathbf{4}\rangle$ 従来研究 乗務員運用計画作成の解法として は, 航空機分野を中心に集合被覆問題の利用 (2) が知られて いる。これを鉄道にあてはめると, 制約条件を満たす範囲 で列車ダイヤ上にある任意の複数本の列車をまとめたもの を行路候補と呼ぶとき，すべての列車をいずれかの行路候 補がカバーするような行路候補の組合せのうち, コストを 最小化するものを求めるものである。ここで, 複数の行路 に同じ列車が含まれる場合にはいずれか 1 つの行路だけが 当該列車への乗務を担当し, 残りの行路は便乗（次乗務開 始駅への移動手段として利用する）として扱うことが考え られるが, 列車乗務と便乗では労働条件（例えば労働時間 の計算方法）が異なることが多く, 同一視して扱うことは できない。これに対応するには, 列車に加え, あらかじめ 想定される便乗を列挙したうえで，すべての列車をいずれ かの行路候補が一度だけカバーする行路候補の組合せを求 める集合分割問題として定式化すればよいが，想定しうる 便乗を加えると行路候補の組合せ数が膨大になるため, 解 探索に多大な時間を要する。

一方, ダイヤ乱れ時の乗務員運用整理においては, 解探 索に許容される時間は計画作成時に比べて極めて短い。特 に，ダイヤ乱れ時には前述したように制約条件の充足より も列車運行の早期復旧が優先されるという背景から, 制約 条件が緩和されることが多く，制約条件の緩和を考慮すれ ば行路候補の組合せは一層増加するため, 集合被覆・分割 問題の適用は必ずしも有効ではない。

\section{3. 乗務員運用整理案の自動作成アルゴリズム}

前章に示したように，現状の熟練者による整理案作成で は目的関数や制約条件が明確に設定されておらず, 熟練者 の裁量で整理案が作成されている。このような状況下では, アルゴリズムだけで熟練者の要求を $100 \%$ 満足する解を作 成することは現実的でなく，アルゴリズムが生成した解を 熟練者が確認し, 必要に応じて目的関数や制約条件を対話 的に修正しながら，試行錯誤できる仕組みとした方が現場 に受け入れられやすい。そこで, 本論文では, 熟練者のも 
つノウハウを盛り込みながら，列車ダイヤ乱れ時に熟練者 による試行錯誤を妨げない程度の時間で乗務員運用整理案 を作成する手法として，メタヒューリスティクスによる解 探索手法を提案する。

提案アルゴリズムでは，熟練者は目的関数が明確でない ことや，現状では制約条件を満たす整理案を作成すること すらできていないことを考慮して，制約条件を充足する運 用整理案の自動作成を目標とする。また，ダイヤ乱れ時に おける乗務員運用整理の制約条件もこれまで明確には定め られていなかったが，ダイヤ乱れ時においてもあらかじめ 定められた条件を可能な限り満たす方が望ましいと考えら れる。そこで，乗務員の労働条件に関する制約条件のうち， 食事時間，休憩時間と拘束時間についてはやむを得ず緩和 することがあるという実態に合わせて緩和可能な制約条件 とし，そのほかは基本計画作成時と同じ制約条件を緩和な しで適用する。

〈3.1〉 行路の分解 ダイヤ乱れに応じて修正された 列車ダイヤ（運転整理ダイヤ）に対して乗務員運用の修正 前計画をあてはめたときに発生する制約違反 (Fig. 2 に丸 印で示す箇所）のうち，時間的に最も早い制約違反の発生 時刻以降を再割当の対象とし，当該時刻以降の行路（図中 の網掛け部分）を列車単位に分解する。各列車が乗務交代 できる駅を跨いでいる場合には，当該駅で列車をさらに分 解する。ここで分解された列車単位が再割当の単位となる。 なお，再割当の対象をダイヤ乱れの発生時刻以降とするこ とも考えられるが，乗務員運用整理では必要のない限りは 原則として元の計画に割り当てることがよいとされるため, ここでは制約違反発生時刻までは割当を変更しない。

また，列車の運転業務はいずれかの乗務員が必ず担当し なければいけないものであるのに対し，便乗は乗務員の次 運転列車への乗継手段として補足的に用いられるものであ るので，計画上で割り当てられていた便乗を必ず再割当し なければならないということはない。そこで，当該時刻以 降の行路に含まれる便乗はすべて削除する。

次に，分解した列車の割当が可能な行路として，現在時 刻に，運用整理案を乗務員に伝達するのに要する時間を加 えた時刻より後まで乗務する予定の行路（整理案作成後に

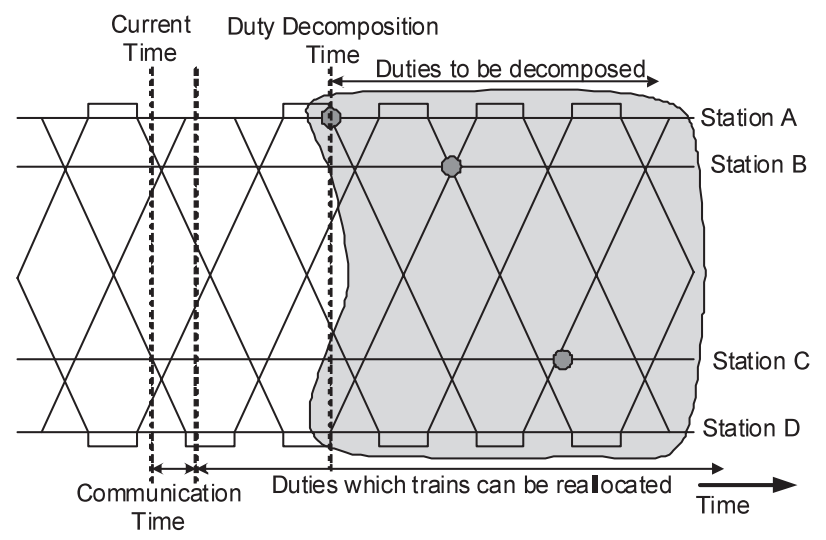

Fig. 2. Scope of analysis—duties to be allocated.
連絡可能な状態にある乗務員の行路を指し，不測の事態に 備えて乗務員区所で待機している予備乗務員や指導員の行 路も含む）を抽出する。また，各行路には乗務員の勤務時 間帯に合わせて，行路開始時刻と行路終了時刻が設定され ているものとする。

ここで，次節に述べる初期解作成において，ある列車の 割当先行路が 1 つもない場合の受け血として，バッファ行 路を用意する。バッファ行路は実際には担当する乗務員の いない行路で，バッファ行路に 1 つでも列車が割り当てら れているような整理案は実行不可能である。バッファ行路 の行路開始時刻と行路終了時刻はいずれも現在時刻に情報 伝達時間を加えた時刻として設定する。

〈3.2〉 初期解作成 初期解作成段階では, Fig. 3 に示 すフローチャートにしたがい, 行路の分解によって未割当 の状態になった列車を始発時刻の早い順にソートしたうえ で, 各列車の割当先としてふさわしい行路を順に決定して 初期解を作成する。

ここで，前節に示したように，バッファ行路に列車を割 り当てると実行可能解にならない。そこで, 初期解作成段 階ではバッファ行路を除く実在の行路（乗務員が割り当て られている行路）にできるだけ多くの列車を割り当てるこ とを目指し, Table 1 のうち, 割当対象行路を絞り込む制約 条件の 1 つである拘束時間上下限の制約条件を除くととも に，ダイヤ乱れ時の運用整理案作成においては，制約条件 の充足よりも列車運行の早期復旧が優先されることを考慮 して，乗務員の労働条件に関する制約条件である食事時間 と休憩時間については一定の範囲内で段階的に緩和するこ とで，列車の実在行路への割当を進める。

ここで, 各列車の割当先行路を決定するにあたっては, 初 期解としての品質を上げるため, 熟練者が割当先行路の決 定にあたって用いるノウハウをもとに作成した割当ルール にしたがって，実在する行路の中から割当先行路の候補を

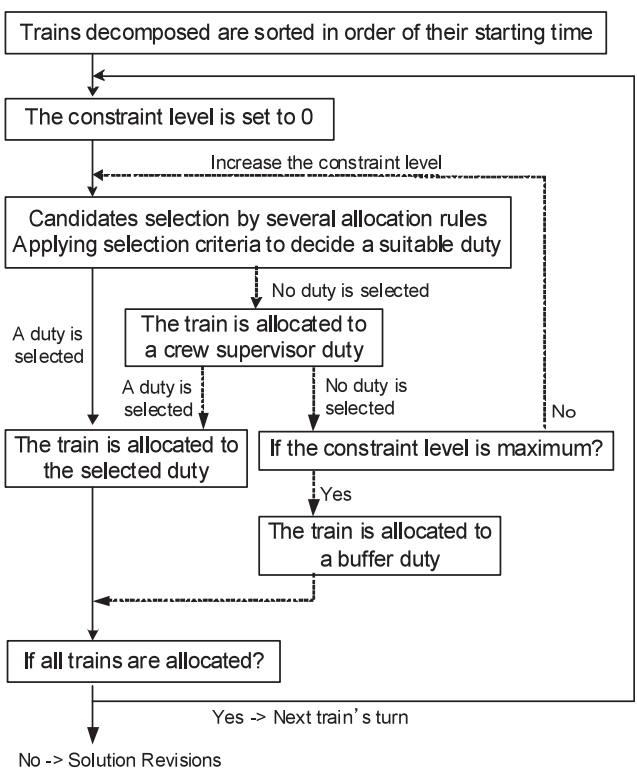

Fig. 3. Process for creating initial solution. 
複数抽出した後, 割当ルールの採用優先順位を定めた選択 知識 (3)を適用して 1 つに絞り込む。

Fig. 4 は割当ルール（Allocation Rules）の例を示すもの である。連続乗務割当 (Continuous drive rule) や最短食事 割当 (Minimal meal rule), 休息最適割当 (Moderate break rule）は，制約条件を満たしたうえで局所的に乗務効率を 上げる割当ルールであり, 計画行路割当 (Plan-duty rule) はあらかじめ定められていた計画と同じ行路に割り当てる ルール，便乗つき割当（Train sharing rule）は別の列車へ の便乗を間に挟むことで割当対象列車の開始駅とは異なる 末尾駅をもつ行路に割り当てるルールである。また，予備 乗務員割当（Reserve crew rule）は，列車を乗務区所で待 機する予備乗務員に割り当てるもので，便乗つき割当と同 じように，行路と列車の間に乗務区所から列車開始駅まで の便乗を割り当てることで, 割当を行いたい列車の開始駅 と異なる末尾駅をもつ行路への割当を許容するルールであ る。このように，それぞれのルールに適合する行路を 1 つ ずつ，列車の割当先行路候補として選ぶ。

次に, 選択知識 (Allocation selection criteria) の例を Table 2 に示す。まず，それぞれの割当ルールに対して得られ た行路候補に対して, 最初の知識を適用し, 知識に該当し ない行路候補を候補から削除する。この結果, 行路候補が 1 つになればそれを列車の割当先行路として決定し, 行路 候補が複数残った場合には，その複数個に対して次順位の 知識を適用する。ただし，ある知識の適用によって，す心゙ ての行路候補が削除される場合には，その知識は適用せず に次順位の知識を適用する。

Table 2 では, 乗務員運用整理においては計画からの変更 量が少ないものが望まれることを鑑み，計画上でもともと 割り当てられていた行路に列車を割当可能であればそれを 優先するという意図で「計画行路に戻す」知識を最上位に 配置し, 計画行路に戻せない場合の対応として, 必ずしも 割り当てる必要のない便乗を増やさない行路や, 食事時間 や休㮩時間をできるだけ確保するという観点から制約条件

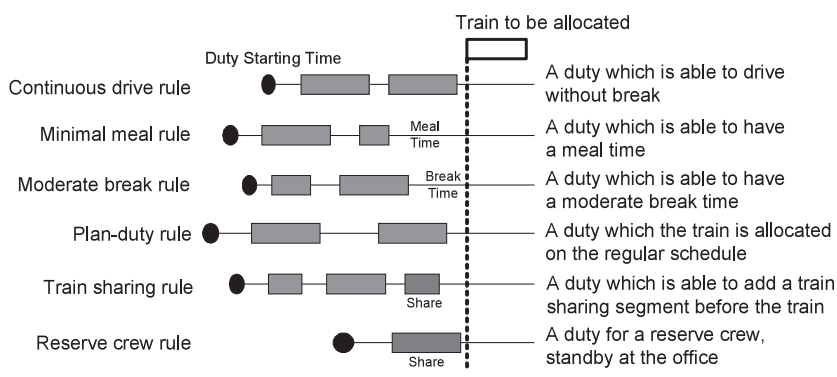

Fig. 4. List of allocation rules.

Table 2. Priority list of allocation-selection criteria.

\begin{tabular}{|c|l|}
\hline Rank & Criteria \\
\hline \hline 1 & Planned duty \\
\hline 2 & Duties where number of train sharings does not increase \\
\hline 3 & Duties where constraints have been relaxed less \\
\hline 4 & Duties that do not exceed time bounds \\
\hline 5 & Duties with minimal crew idle time \\
\hline
\end{tabular}

緩和の程度が小さい割当を行う行路, 残業をしなくてすむ 行路をそれぞれ優先するといった順位づけを示している。

ここで，それぞれの割当ルールに該当する行路候補が 1 つも抽出されなかった場合には, 選択知識を適用する行路 候補がないため, 列車の割当先行路がなくなる。このよう な場合には, 通常は乗務員の監督・指導業務を担当する指 導員に割り当てる。なお，指導員の滞在場所と列車開始駅 が異なる場合には, 予備乗務員の場合と同様に, 滞在場所 から列車開始駅までの便乗を割り当てる。

一方，列車開始駅に間に合う指導員がいない場合には， ある制約条件レベルのもとでは当該列車を割り当てる実在 行路は存在しないことになる。このような場合には, Fig. 3 のフローチャートに沿って制約緩和レベルを 1 段階上げる ことで，食事時間抢よび休㮩時間の制約を緩和して再度割 当を試みる。制約緩和レベルが最大段階まで達してもなお 割当先行路がない場合には, いったんバッファ行路に割り 当て, 次節に述べる解修正に扔いて, 実在行路への移動を 探索することで実行可能解の作成を行う。

$\langle 3 \cdot 3\rangle$ 解 修 正 Fig. 5 に示すフローチャートにした がって初期解を修正することにより, バッファ行路への列 車割当と初期解作成時には考慮しなかった拘束時間上下限 に関する制約違反を解消する。

ここで, 拘束時間上限は許容される残業時間の上限を定義 するものであり, 乗務員の都合に合わせて行路終了時刻 $+\alpha$ として設定し,拘束時間下限は, 他の行路との間で拘束時間の ばらつきを抑えるために設けるものとして, 行路終了時刻一 $\beta$ として設定する。また，バッファ行路については，拘束時 間上限・拘束時間下限とも現在時刻十情報伝達時刻に設定 する。このような設定のもと，各行路における制約違反の 程度を, Fig. 6 に示すように拘束時間上下限からの超過分 に比例するように数值化する。また，バッファ行路につい

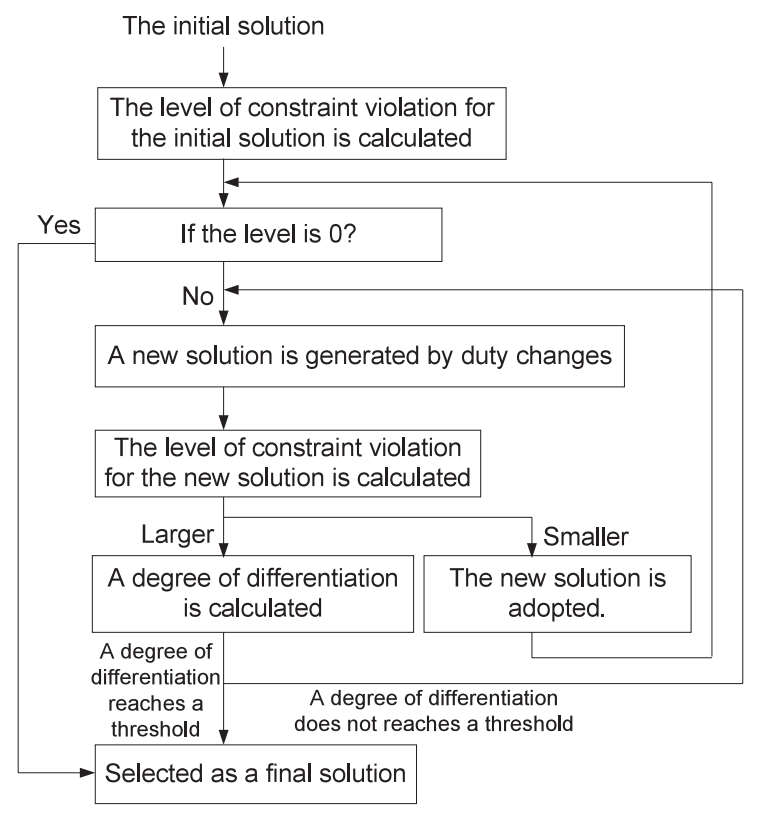

Fig. 5. Solution revision flow chart. 
ては超過分に対する違反度の傾きをより大きく設定するこ とでバッファ行路から通常行路への列車の移動を進める。

なお，初期解作成時に食事時間と休憩時間に関する制約 条件を緩和した場合にはこれらの不足分を違反度に加える ことも考えられるが，現実の運用においては食事時間・休 憩時間に比べて拘束時間の方が制約遵守の要求がより高い ことを踏まえ，ここでは拘束時間のみで違反度を構成した。

そして, 以下に示す 2 つのオペレーションのいずれかを 遂行してできるすべての行路变更のうち 1 つを選択する処 理を繰り返すことにより，すべての行路における違反度の 和を最小とする解の探索を行う。

(a) 任意の 1 行路に含まれる列車を他行路に移動する

(b) 任意の 2 行路間で列車を交換する

また，このとき，局所解に陥ることを防ぐため，組合せ 最適化問題におけるメ夕戦略の 1 つであるタブーサーチ ${ }^{(4)}$ を用い, 行路間での列車の移動履歴をタブーリストに登録 し，過去に探索済みの列車移動を抑制する。なお，タブー リスト長は無限大とし, 探索済みの最良解より良い解を発 見するとタブーリストをクリアする。また，探索の終了基 準として, 探索中の解のうち探索済み最良解と異なる行路 に割り当てられている列車の数を示す相違度を定義し, 相 違度がある閾值に達した時点で探索を打ち切る。

\section{4. 適用事例}

〈4・1〉対象路線提案アルゴリズムの有用性を示す ために，首都圈にある都市近郊線区の 1 つである中央総武 緩行線への適用評価を行った。

中央総武緩行線の駅および区所の配置は Fig. 8 に示す通 りである。図中に実線で示した中央緩行線線区（三鷹一御茶 ノ水）と総武緩行線線区（御茶ノ水一千葉）の普通列車が整 理案作成の対象であり，両線区に乗り入れている特急・快 速列車 (図中点線部) は含まない。

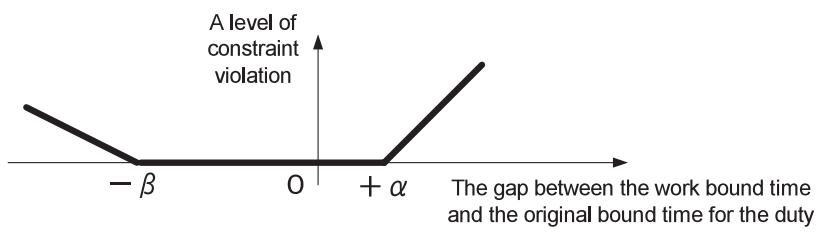

Fig. 6. Definition of violation level.

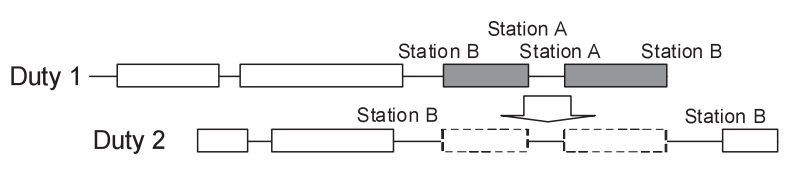

(a) Move an arbitrary sequence of trains within one duty to another

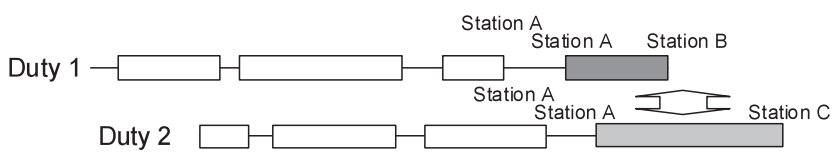

(b) Swap arbitrary sequences of trains between two duties

Fig. 7. Examples of duty revision operations.
これらの線区には 39 駅があり，うち運転士の交代が可能 な駅は 6 駅である。また，1 日に運用される行路数は 163 , 列車本数は 1260 である。運転士は中野電車区または習志 野運輸区のいずれかに所属し, 泊まり行路担当者の一部を 除いては所属区所にて勤務を開始・終了する。

〈4・2〉提案アルゴリズムの適用 中央総武緩行線に 対応した制約条件のもとで提案アルゴリズムにしたがって 運用整理案作成を行う。

ここで, 中央総武緩行線に乗り入れている特急・快速列車 は整理案作成の対象外であるが，中央総武緩行線を担当す る乗務員の中には行路の一部で特急・快速列車に乗務する 者もいる。このとき, 中央総武緩行線のダイヤ乱れによっ てこれらの乗務員の行路に変更が生じることで, 特急・快 速列車の運行にも支障が出ることを避けたいとの要請があ る。そこで, Fig. 9 に示すように, 行路の分解時に特急・快 速列車への乗務は行路から分解せずに, 固定の割当として 行路に残し，初期解作成および解修正では固定列車を除く 部分に，制約条件を満たしながら固定列車と接続できるよ うに列車の割当を行うことにした。

また, 拘束時間上下限については, 全乗務員とも $\alpha=\beta=$ 2 時間としたうえで, 翌日早朝の乗務のために区所で滞泊 する乗務員については，翌日行路開始時刻との間に一定の 仮眠時間を確保できるように，拘束時間上限を修正した。

$\langle\mathbf{4} \cdot \mathbf{3}\rangle$ 適用結果 中央総武緩行線で過去に実際に発 生したダイヤ乱れ 2 種類に対し提案アルゴリズムを適用し て作成した自動整理案と, 熟練者の作成記録から復元した 人間整理案を比較した結果を Table 3 に示すとともに, 両 整理案の行路を棒形式で表したものを Fig. 10 に示す。

なお，ダイヤ乱れ発生時の詳しい情報（ダイヤ乱れの発 生時刻や遅延情報の取得時刻，区所に待機する予備乗務員 の人数など）が保存されていなかったため, 提案アルゴリ ズムの適用にあたっては, 最初の運転整理 (ダイヤ変更) が 行われた時刻を現在時刻として実行した。また，予備乗務 員は，熟練者による運用整理時に実際に使用された人数だ け存在し, それぞれの拘束時間は現在時刻から運転士の標 準運用基準にしたがって 7 時間 10 分とした。

最初に, Table 3 に示す比較結果において, 拘束時間 (Working hours ; 全乗務員の拘束時間の和) や便乗回数（No. of shares; 全乗務員の便乗数の和), 予備乗務員の使用人数 (Re-

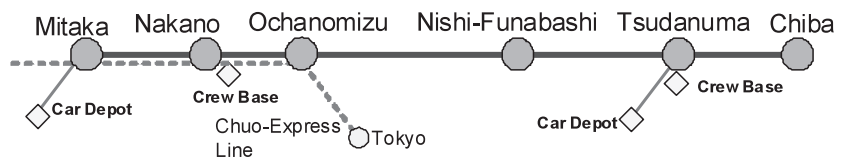

Fig. 8. Chuo-Sobu local line.

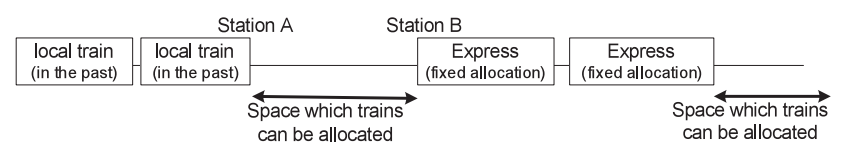

Fig. 9. Consideration of fixed trains. 
Table 3. Comparison of Manually and automatically generated modifications.

\begin{tabular}{|c|c|c|c|c|c|c|c|c|}
\hline \multirow{2}{*}{ Case } & \multirow{2}{*}{ Type } & \multicolumn{2}{|c|}{ Working hours } & \multirow{2}{*}{$\begin{array}{l}\text { No. of shares } \\
\quad \text { (\# trains) }\end{array}$} & \multirow[b]{2}{*}{ Plan ratio } & \multirow{2}{*}{$\begin{array}{c}\text { Reserve } \\
\text { crews } \\
\text { (\# crews) }\end{array}$} & \multirow{2}{*}{$\begin{array}{c}\text { Changed } \\
\text { crews } \\
\text { (\# crews) }\end{array}$} & \multirow{2}{*}{$\begin{array}{l}\text { Computing } \\
\text { time (s) }\end{array}$} \\
\hline & & $\begin{array}{l}\text { Absolute } \\
\text { value (s) }\end{array}$ & $\begin{array}{l}\text { Relative } \\
\text { increase }\end{array}$ & & & & & \\
\hline \multirow{2}{*}{1} & Manual & 3672110 & - & 59 & $95.4 \%$ & 2 & 14 & - \\
\hline & Automatic & 3656790 & $-0.42 \%$ & 60 & $96.5 \%$ & 0 & 15 & 3.7 \\
\hline \multirow{2}{*}{2} & Manual & 3679270 & - & 68 & $96.9 \%$ & 2 & 39 & - \\
\hline & Automatic & 3660040 & $-0.53 \%$ & 65 & $96.7 \%$ & 2 & 32 & 10.2 \\
\hline
\end{tabular}

\# Machine Performance: (CPU) Pentium 4-2.8GHz, (Memory) $1 \mathrm{~GB}$
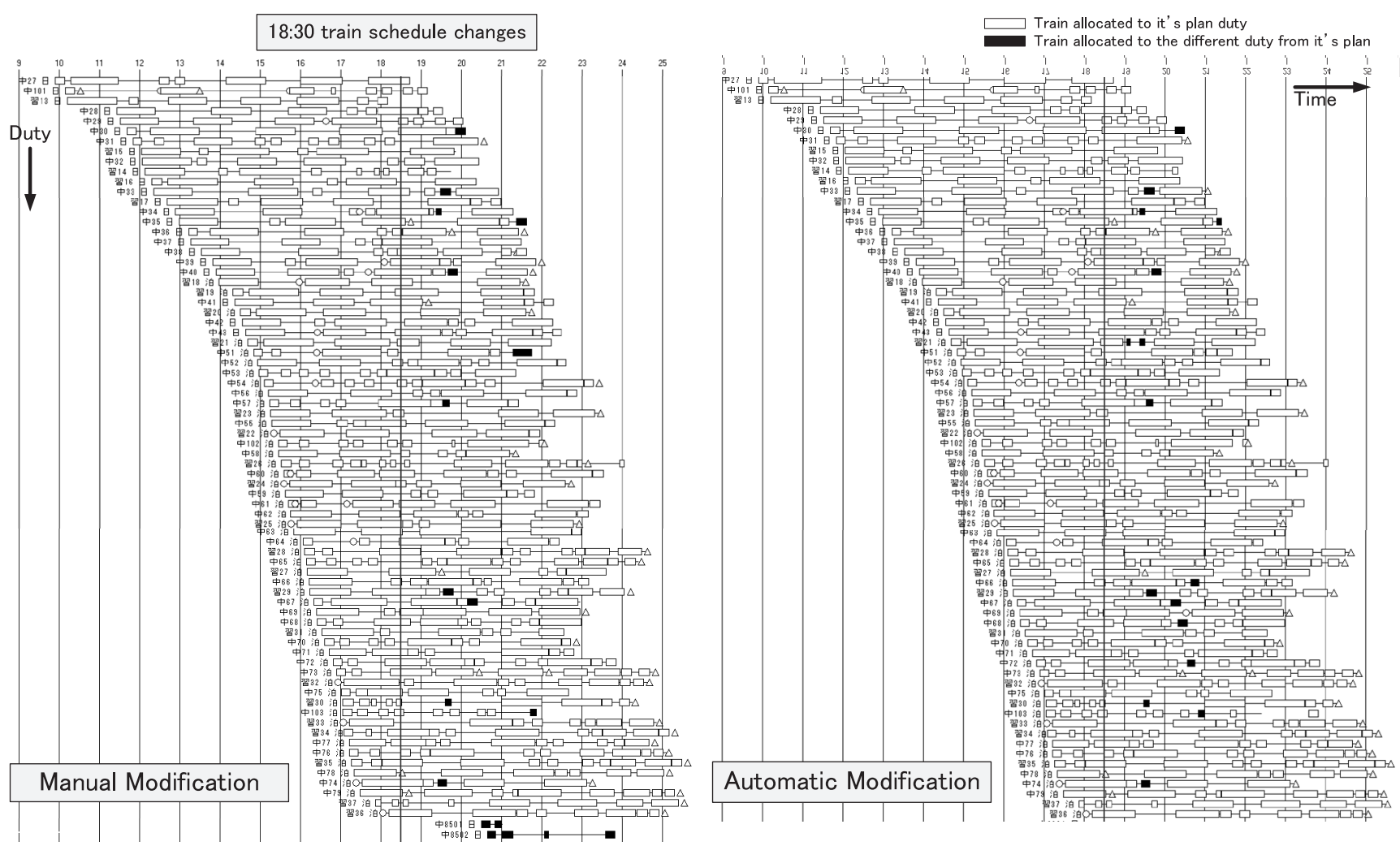

Fig. 10. Visual comparison of manually and automatically generated modifications.

serve Crews）は少ない方が効率のよい整理案であることを 示し，ダイヤ乱れの早期復旧という観点からは，計画比率 (Plan ratio；計画と同じ行路に割り当てられている列車の比 率) は高い方がよいとされる。また，乗務員への伝達の手 間を考えると，変更した行路の数 (Changed crews) は少な い方が好ましいとされるが，自動整理案はすべての指標で 人間整理案とほほ同等または同等以上の評価值を得られた。

また，手作業による運用整理案作成では担当者の負荷が 高いことが課題の 1 つであったが, 自動整理では, 担当者 との対話的な修正にストレスを感じさせない程度の時間で 実行可能解を得られることが分かった。

さらに, Fig. 10 は, Table 3 の Case1において，現在時 刻以降に乗務する行路をその開始時刻の早い順に各行に並 べ，各行路に割り当てられた列車を矩形で表現したもので あり，そのうち計画と同じ行路に割り当てられた列車を白 抜き矩形，計画と異なる行路に割り当てられた列車を黒抜 き矩形で描画している。乗務員運用整理では，ダイヤ乱れ
への適応力を測る指標として修正前計画への収束までに要 する時間がしばしば利用されるが，両整理案に大きな差は なく，この点でも自動整理案は人間整理案と少なくとも同 等の品質をもつと言える。

\section{5. おわりに}

計算機を用いた列車運行管理システムの運用は急速に広 がっているが, 列車運行の元になる列車運行計画や車両 . 乗務員運用計画はいまだに熟練者の手作業で作成されてい る。本論文では，このうち鉄道事業者のニーズが高いダイ ヤ乱れ時における乗務員運用整理案（乗務員運用計画の変 更案）の自動作成アルゴリズムを提案した。提案アルゴリ ズムは, 一部の制約違反を許容して初期解を作成した後, 初 期解作成時に許容した制約違反の程度を示す違反度を最小 化するように，タブーサーチを用いて解の修正を行うよう に構成したものである。

また，現在の熟練者による手作業を提案アルゴリズムに 
よる自動化に置き換えるためには，提案アルゴリズムが単 に制約条件を満たす解を作成できるというだけでなく, 熟 練者が満足できる整理案を作成できることを示す必要があ る。そこで, 提案アルゴリズムを中央総武緩行線に打ける 2 種類の乱れダイヤに適用した結果を熟練者の手作業による 整理案と比較し, 提案アルゴリズムが熟練者と同等以上の 評価をもつ実行可能解を短時間で作成できることを示した。

今後は, よりさまざまな乱れダイヤや線区への適用評価 を繰り返すことでアルゴリズムの改良を進め，自動提案機 能の実用化を目指す所存である。

(平成 20 年 2 月 28 日受付, 平成 20 年 6 月 11 日再受付)

\section{文献}

（1）(財）鉄道総合技術研究所 運転システム研究室 著: 鉄道のスケジュー リングアルゴリズム, NTS 出版 (2005)

(2) D. Wedelin: "An algorithm for large scale 0-1 integer programming with application to airline crew scheduling", Annals of Operations Research, Vol.57, pp.283-301 (1995)

（3）竹田真也・階良知・片岡健司・薦田憲久：「状態選択法と条件緩和 探索法による知識型乗務員運用計画方式」, 電学論 C, Vol.119, No.11, pp.1377-1382 (1999)

（4）柳浦睦憲・茨木俊秀：組合せ最適化〜メ夕戦略を中心として〜, 朝 倉書店 (2001)

高 橋 理 (正員) 1971 年生。1996 年 3 月大阪大学大学院

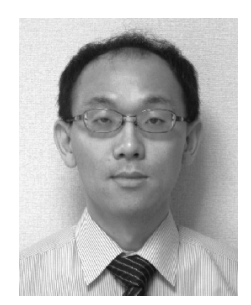
基礎工学研究科博士前期課程修了。同年 4 月三菱 電機 (株) 入社。現在, 同社先端技術総合研究所に て，システム工学やオペレーションズリサーチの 鉄道システムへの応用に関する研究開発に従事。 博士 (工学)。日本 OR 学会, 日本信頼性学会な どの会員。

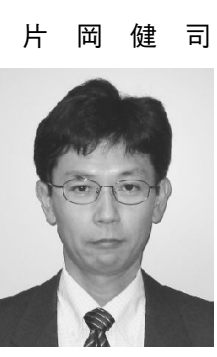

(正員) 1964 年生。1989 年 3 月大阪大学大学院 工学研究科通信工学専攻博士前期課程修了。同年 4 月三菱電機（株）入社。現在，同社先端技術総 合研究所にて, 鉄道向け運行管理システム, 信号 保安システムなどの研究開発に従事。工学博士。

小 島 央 \pm (非会員) 1971 年生。1995 年 4 月東日本旅客鉄

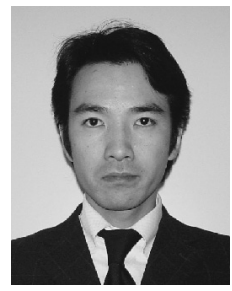
道（株）入社。JR 東日本研究開発センターにて, 輸送指令業務，乗務員運用整理業務の支援システ ムに関する研究開発に従事。2008 年 4 月より本 社運輸車両部にて, 車両運用計画に関する業務に 従事。

浅 見 雅 之 (正員) 1975 年生。1999 年 4 月東日本旅客鉄道

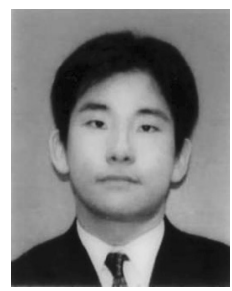
(株) 入社。JR 東日本研究開発センターにて, 車 両・乗務員運用整理業務の支援システムに関する 研究開発に従事。2008 年 4 月より（財）鉄道総 合技術研究所に出向し, 輸送計画・運転整理の支 援システムに関する研究開発に従事。情報処理学 会会員。 